\title{
Cost of Piracy: A Comparative Voyage Approach
}

\section{IAME 2009}

Copenhagen

24 -6 June 2009

\section{Section 1: Shipping Market Analysis}

\begin{abstract}
The seizure by Somali pirates of the Saudi owned VLCC, the Sirius Star with its crew, in November 2008 captured international attention. Across the world regular updates were given and the ransom demands discussed and debated in the press. Dramatic footage was shown on national television of the payment of the ransom by parachute and footage of the debacle which followed where some of the pirates were drowned. Until then, most of the non-shipping world thought of pirates as the romantic buccaneers aka Hollywood. However the cost to industry and its impact on international trade of piracy cannot be ignored. There are potential geopolitical repercussions. Despite international efforts, piracy in this region threatens to put a chokehold on one of the world's busiest shipping arteries. Shipping lines are taking decisions to avoid the area and rerouting via the Cape of Good Hope. This paper attempts to measure the costs of piracy from the shipping company's perspective by taking a comparative voyage costing approach.
\end{abstract}

Dr Helen B Bendall

Finance and Economics.

University of Technology, Sydney

PO Box 1, Ultimo, Sydney

NSW 2007.Australia

Helen.Bendall@uts.edu.au

\section{Key Words}

Piracy, comparative voyage costing, opportunity costs, diversion costs, Suez, Somalia 


\section{INTRODUCTION}

Piracy is now a high-profile issue in international trade and transport. Despite international efforts, the age-old scourge of piracy is thriving with pirates terrorizing some of the world's busiest shipping lanes. In the last ten years shipping companies have been subject to a steep rise in the number of pirate attacks on their vessels. These attacks have a direct impact on the cost of merchant shipping and thus indirectly on international trade and globalisation. Insurance premiums of ships travelling through pirate-infested waters have risen and that rise affects freight rates. These rises are ultimately passed on to businesses and consumers as increased costs. Every year hundreds of ships are attacked and the crew killed, injured, traumatised or taken hostage. Ransoms are paid and insurance premiums soar. The international response has been to send navies to protect merchant shipping and international trade. To avoid trouble spots owners may make a decision to divert vessels but this will not only add considerable operating expenses as fuel costs rise but the additional time spent in rerouting vessels limits the number of voyages per year and thus revenue making opportunities. If piracy is not combated and continues to grow, it will have serious consequences for international transport and trade, affecting both developed and developing economies.

The paper will firstly examine the growth in piracy in modern times and discuss some of the legal complexities facing the international community in trying to combat and obtain a prosecution for acts of piracy. The impact on international shipping and trade and the total cost worldwide of combating piracy has been difficult to estimate. This paper will use comparative voyage costing approach to show the financial impact of piracy on shipping lines which chose to re-route to avoid known pirate trouble spots.

\subsection{Pirate attacks in the $21^{\text {st }}$ century.}

The statistics are alarming.

In 2008 there were 293 acts of piracy against ships, more than $11 \%$ up from the previous year where there were 263 incidents. In the first two months of 2009 there have been 26 more (IMB 2009a). Of the 293 pirate attacks in 2008, 49 vessels were hijacked, 889 crew taken hostage and a further 46 vessels fired upon. A total of 32 crew members injured, 11 killed and 21 missing presumed dead (IMB 2009b). These are the reported incidents. The IMB believes that actual pirate attacks could be possibly double those reported as many shipping lines prefer to cover losses out of their own resources rather than risk additional insurance costs. They fear as well, alarming customers, the time delay impacting on lost revenue potential and port costs of incurred while an investigation takes place.

In 2008 there were 111 incidents reported to the IMB off the east coast of Somalia and in the Gulf of Aden, an increase of 200\% over 2007 figures. The International Chamber of Shipping claims that pirates attack one ship in ten in the area, although most are 
unsuccessful. The IMB is concerned that successful attacks are being carried out at greater distances from the land than in previous years. All types of vessels with varying freeboards and speeds were targeted. The pirates were better armed than in previous years and prepared to assault and injure the crew (IMB 2009b).

The major areas for pirate attacks are The Gulf of Aden, near Somalia and the southern entrance to the Red Sea; The Gulf of Guinea, near Nigeria and the Niger River Delta; The Strait of Malacca between Indonesia and Malaysia, the Indian subcontinent, particularly between India and Sri Lanka and Central and South America (Hanson 2009; IMB 2009a). Shipping carries $90 \%$ of international commerce and as major shipping routes take cargo ships through narrow bodies of water such as the Strait of Malacca and the Gulf of Aden this provides an ideal opportunity for pirates to attack and board vessels using small high powered speed boats, often controlled by a mother ship (The Economist $2008 \mathrm{~d}$ and e).

The attack on the Sirius Star, one of the largest oil tankers in the world, 450 nautical miles off the coast of Kenya on 15 November 2008 focused world attention on the issue. It was the biggest ever "catch" by any pirate anywhere in the world, highlighting the vulnerability of even very large ships. The VLCC was carrying $\$ 110$ million worth of oil. The ransom demanded initially was $\$ 30$ million but when Resolution $1846^{1}$ was passed by the United Nations Security Council giving the international community more powers to apprehend pirates in Somali territorial waters, the pirates demand was reduced to $\$ 3$ million and ultimately paid by a dramatic parachute drop, recorded on film and shown live over international television networks to a worldwide audience. However it must be remembered that there are still an estimated 300 crew from freighters and pleasure craft still being held hostage by Somali pirates (Costello 2008) ${ }^{2}$.

\section{Who are pirates and what constitutes an act of piracy?}

Piracy has always provided a good opportunity for ruthless men to seek their fortunes, experience the thrill of danger and engage in casual violence and cruelty (Cordingly 2006).

\footnotetext{
${ }^{1}$ Four Resolutions were passed during 2008 in an attempt to reduce the growing number of pirate attacks in the Gulf of Aden and give more legitimacy for the Navies operating in the area to protect vessels and apprehend pirates. UN Resolution 1846, passed on 2 December 2008 permits States and regional organisations cooperating with the Somali Transitional Federal Government,(TFG) to enter Somali territorial waters and use "all necessary means" such as deploying naval vessels and military aircraft, as well as seizing and disposing of boats vessels, arms and related equipment used for piracy.......to fight piracy and armed robbery of the sea off the Somali coast, in accordance with relevant international law.

${ }^{2}$ Pirates are demanding a $\$ 1.4 \mathrm{~m}$ ransom for two French nationals and their yacht seized in September and are still being held in Somali.
} 
Etymological dictionaries trace the word pirate directly from the Latin, pirata but ultimately to Greek roots; Peirates, meaning "brigand", and peira "to attempt, experience and find luck on the sea". Acts of piracy have become part of folklore since antiquity as waterways, seas and oceans began to be used as trade routes. Pirates, robbed, maimed, killed and captured people for mercenary gain. In the $13^{\text {th }}$ Century BC the Sea Peoples were one of the first whose exploits were documented terrorising the Aegean and Mediterranean Seas. The Phoenicians although great traders who were the victims of pirate attacks in the Mediterranean, at times resorted themselves to acts of piracy, capturing and trading in slaves. Julius Caesar in $78 \mathrm{BC}$ was captured and ransomed by Cilician pirates as was St Patrick in 5 th century who was enslaved by Irish pirates. The stories of Viking raids plundering Britain, Ireland, Europe and Russia are renowned. Muslim pirates terrorized the Mediterranean towards the end of the $9^{\text {th }}$ century. Nor was piracy confined to known world of Western Europe and the Mediterranean. Pirates have operated in Eastern Europe, Africa, Asia and Polynesia throughout history.

In recent times, the romantic notion of the privateer ${ }^{3}$, cutlasses, Jolly Rogers and walking the plank have been replaced by sophisticated operations with pirates using fast speed boats with the power to outrun most modern day freighters. Their vessels have the latest satellite communication and positioning systems. Pirates are armed with assault rifles, rocket launches and grenades. Captured vessels are typically held on average for three months before a ransom, which averages $\$ 1$ million, can secure the vessel and crew release (Costello 2008). It is estimated that in 2008 Somali pirates had netted $\$ 120$ million in ransom payments (Gettleman 2009). One of the biggest marine insurance payouts pay-outs was around $\$ 70 \mathrm{~m}$ in an attack by pirates off Yemen in 2002 on the French tanker, the Limberg. One of the concerns of the international community are the links to armed Islamist groups. Ransoms are an ideal funding source for terrorists since the international banking system has tightened up $^{4}$. There is however a distinction between acts of terrorism and piracy from a legal point of view with regard to rights of pursuit and penal sanctions which has created a problem for the international community's attempt to protect international shipping.

\footnotetext{
${ }^{3}$ A privateer was an armed vessel sanctioned by a State and authorised to capture the merchant vessel of a hostile nation. Privateering invariably flourished during time of war but degenerated into piracy when peace was declared. (David Cordingly 2006).

${ }^{4}$ The MV Faina, a Ukrainian freighter was captured in September 2008 with a cargo of Soviet-era tanks and other heavy weapons bound for Southern Sudan with the connivance of the Kenyan government (The Economist $2008 \mathrm{~d}$ and e). Many believe the action was engineered by the ICU, Islamic Courts Union (Hanson 2009)
} 


\subsection{Legal definition, issues and problems}

The term "piracy" was defined by the Geneva Convention on the High Seas in 1958 and was adopted by the UN 1982 Convention. The United Nations Convention on the Law of the Sea (UNCLOS) states in Article 101 that piracy consists of any illegal acts of violence, or detention, or any act of depredation, committed for private ends by the crew or the passengers of a private ship or private aircraft that is directed on the high seas against another ship, aircraft, or against persons or property on board such ship or aircraft. It specifically states that the act can occur outside the jurisdiction of any state and includes any act of voluntary participation and any act of inciting or of intentionally facilitating an act of piracy. For acts of violence against ships, persons, or property on board to be classified as piracy the following conditions must all be met simultaneously: The act of violence must be committed by the crew or passengers of another vessel, is illegal and serve private purposes and it must be committed on the high seas or at a place not subject to state sovereignty (House of Commons 2006; IMO 2000).

Although appearing quite comprehensive, there are legal issues which have limited the enforcement of the Convention. For example Article 101 does not include politically motivated acts, such as terrorist attacks which in more recent times have become blurred. Many believe that the sophistication of more recent attacks demonstrates the links to al Queda. The Institute for South East Asian Studies, ISEAS, report that it is al-Qaeda intention to disrupt maritime trade, targeting especially industrialised countries dependence on oil. Particularly of concern is the potential for the Straits of Malacca or the Suez to be blocked which would force forcing costly diversions and add to world commodity prices. Intelligence reports show that al-Qaeda has its own naval manual with entries showing which points to target on a vessel, how to attach limpet mines, how to fire rockets from a speedboat travelling at high speed and how to transform gas tankers into flowing bombs (Munich Re 2006). Pirates have provided training to the maritime wing of al-Shabaab, and al-Shabaab is using some pirate groups for arms smuggling (Schiemsky 2008)

The definition of what is meant by "illegal" has led to debate in Court under whose law the act of piracy should be considered. Should it be judged from the perspective of international law or national law in the prosecuting countries? Should it be under civil or penal code? The problem is exacerbated as every legal system has its own definition of the act of piracy. Another shortcoming is that $80 \%$ of all attacks occur in territorial waters and in ports and thus do not qualify as piracy under the UN 1982 Convention which limits the offence to the high seas. However the 2008 UN Resolution, although specifically aimed at the problem in Somali, does give some precedence to apprehend pirates in a State's territorial waters.

The complexity of the legal situation and the problem of obtaining a conviction can be best illustrated with the following case example. 
A vessel flying a Panamanian flag is carrying a shipment from Japan. The cargo is insured in Germany, the crew comes from the Philippines and the Netherlands. The vessel has been boarded on the high seas by Indonesian pirates. Which law applies ${ }^{5}$ ?

\subsection{Measuring the costs of piracy.}

There is no quantitative research available on the total cost of piracy (Hanson 2009), nor any reliable figures documenting the economic consequences (Munich Re 2006). Estimates vary widely because of disagreement as to how to measure the costs of piracy. What variables should be included? Are insurance risk premiums, ransoms and the costs of negotiation including the time factors the key variables? What about the impact on world trade and value put on the human the trauma suffered by crew and family? Should the cost of the combined international force of navy ships patrolling the Gulf also be factored in?

Published estimates vary between $\$ 1$ billion to $\$ 16$ billion a year (Hanson 2009; Bone 2008) with most commentators agreeing it is extremely difficult to estimate. Others warn against exaggerating the current threat posed by modern day pirates. Some experts argue that even if the costs are $\$ 16$ billion pa this should be put into perspective as it is a very small proportion of total value of world commerce which is in the order of trillions of dollars per annum (Hanson, 2009). However there is no doubt that there is growing concern in the international community because of the scale of attacks and the size of the vessels now being targeted. In 2007 for instance 6,500 tankers carrying 7\% of the world's oil used the Suez Canal route (Miller 2008). Others warn that there are possible links to terrorists. They are concerned that if the Suez Canal was blocked by a terrorist act that this would choke off $11 \%$ of world trade. Another fear is the possibility of an environmental disaster involving a large $\mathrm{VLCC}^{6}$ which could have serious consequences or a potential lethal cargo falling into the wrong hands ${ }^{7}$

One measure of the cost of piracy could be from the point of view of the Suez Canal Authority. As ships avoid the region their revenue has fallen. Under normal operating conditions around 20,000 vessels transit the Canal annually. The company has reported that piracy in the Gulf of Aden/Somali has reduced Canal traffic by $45 \%$ to $50 \%$ on normal

\footnotetext{
${ }^{5}$ See discussion in (Munich Re 2006).

${ }^{6}$ There is fear that there could be a repeat of a pirate hijacking incident in the Malacca Strait. In 1992 a collision occurred between the containership "Ocean Blessing" and a hijacked tanker "Nagasaki Spirit" taking the lives of all but two of both ship's crew. Pirates boarded the tanker, imprisoned the crew and set the auto pilot at full speed. The fire lasted for six days on tanker and six weeks on the container ship. (Law Lords 1997).

${ }^{7}$ In late September2008 an Iranian ship on route from China was boarded by pirates. Some pirates died while others experienced sickness, hair loss or suffered burns, leading to speculation of chemical or radioactive cargo. (Abrams 2008)
} 
volumes. On a daily basis volumes are about 70 to 80 vessels northbound and southbound and now only half that are using the Canal due to the present problems (Ostler 2009). If we look at for example at container vessels, $26.5 \%$ of all international container traffic passed through the Suez Canal carrying 20.5million TEUs in 2007 (Fetouh 2008). Larger container vessels incur a transit fee about $\$ 600,000$ so any drop in the volume of ships has an immediate impact on the Suez Canal Authority's bottom line and implications for foreign exchange earnings of the Egyptian Government. As a direct result of this drop in volume, Canal rate rises scheduled for 2009 have been shelved and a fall in dues is being contemplated.

Many shipping companies are now prepared to re-route via the Cape of Good Hope, despite that this will add thousands of miles to the journey. Table 1 shows the savings of the Suez route in nautical miles and as a percentage of the total voyage for selected port pairs.

Table 1 Savings in nautical miles and \% of voyage via Suez Canal

\begin{tabular}{|c|c|c|c|c|c|}
\hline \multirow{2}{*}{ From } & \multirow{2}{*}{ To } & \multicolumn{2}{|c|}{$\begin{array}{c}\text { Distance Nauntical } \\
\text { Miles (NM) }\end{array}$} & \multicolumn{2}{|c|}{ Savings } \\
\hline & & Suez Canal & CAPE & NM & $\%$ \\
\hline \multirow{4}{*}{ Ras Tanura } & Constantza & 4,144 & 12,094 & 7,950 & 66 \\
\hline & Lavera & 4,684 & 10,783 & 6,099 & 57 \\
\hline & Rotterdam & 6,436 & 11,169 & 4,733 & 42 \\
\hline & New York & 8,281 & 11,794 & 3,513 & 30 \\
\hline \multirow[t]{3}{*}{ Jeddah } & Piraeus & 1,320 & 11,207 & 9,887 & 88 \\
\hline & Liverpool & 3,902 & 10,702 & 6,800 & 63.5 \\
\hline & Rotterdam & 6,337 & 10,743 & 4,406 & 41 \\
\hline \multirow[t]{2}{*}{ Bombay } & Rotterdam & 6,337 & 10,743 & 4,406 & 41 \\
\hline & Marseille & 4,558 & 10,362 & 5,804 & 56 \\
\hline Tokyo & Rotterdam & 11,192 & 14,507 & 3,315 & 23 \\
\hline Shanghai & Genoa & 8,670 & 13,619 & 4,947 & 36.3 \\
\hline Singapore & Rotterdam & 8,288 & 11,755 & 3,647 & 29 \\
\hline
\end{tabular}

Source: Derived from information provided by the Suez Canal Authority

CMA CGM who operate one of the world's largest container fleets has announced its intention to divert some of their services via the Cape (Porter 2009). MSC has also announced its intention to take the longer route via the Cape and Maersk has already done so for some of it container services (Lloyd List DCN 2009a; Port Strategy 2009). Frontline, the 
world's largest operator of supertankers, said after the hijacking of the Saudi VLCC, Sirius Star, that they would consider diverting vessels (Abdul Bashi 2008). Odfjell SE, a Norwegian company with 100 chemical tankers has begun diverting its vessels around Africa at an extra cost of $\$ 30,000$ per day, even though the route adds five days on a run from Asia and ten days from the Middle East (Miller 2008). MOL is now diverting some of its pure car and truck carriers around Africa and the Grand Alliance - Hapag-Lloyd, NYK, OOCL and MISC would reroute their eastbound EU3 sailings to void Suez (Lloyds List DCN b).

Diverting vessels around the Cape of Good Hope will add thousands of nautical miles to many trades and thus this decision needs to be quantified by determining the net benefit or cost to the shipping line. This is a measure of the cost of piracy from a ship operator's perspective and it is this measure that will be pursued in this paper. In Section 2 the model is explained and comparative cost component values determined to be used in Section 3 to calculate the costs of piracy. Section 4 concludes the paper.

\section{MODEL AND COST COMPONENTS}

Ship operators are assumed to maximise profit - voyage revenue less costs so

$$
P=R-C
$$

where

$$
\begin{aligned}
& P=\text { profits } \\
& R=\text { revenue } \\
& C=\text { costs }
\end{aligned}
$$

On the revenue side,

$$
\begin{aligned}
& R=f(V, r) \\
& V=\text { cargo carrying capacity } \\
& r=\text { freight rate }
\end{aligned}
$$$$
\text { where }
$$

Ceteris paribus freight rates, $r$, in this analysis are considered given and independent of the route, as freight rates reflect competitive market conditions. Similarly, the cargo carrying capacity per voyage, $V$, is taken as given as it will not vary with route chosen. On these grounds there is no need to consider the revenue function further so attention will be focused on costs. The costs considered will be those that vary directly with the route chosen ie the voyage costs, $V_{C}$, while those costs associated with stevedoring, port and light dues, wharfage at the loading and destination ports will be considered constant and will not enter into the analysis. Thus 


$$
V_{C}=f\left(N, F, C_{S C,}, T\right)
$$

where

$$
\begin{aligned}
N & =\text { nautical miles } \\
F & =\text { fuel cost } / \text { voyage } \\
C_{S C} & =\text { Suez Canal transit costs } \\
T & =\text { Time period }
\end{aligned}
$$

To measure the cost of piracy for the ship operator only those operating costs and overheads such as insurance which alter when the longer route via the Cape of Good Hope is undertaken ie the incremental voyage costs, $\Delta C_{V}$, are relevant, The most important component of these costs is the change in fuel cost, as the route via the Cape adds significant number of nautical miles to the voyage. However there are offsetting cost adjustments which need to be made if the Suez route is used. The Suez Canal rates for pilotage and to transit the Canal both southbound and northbound are considerable. As well, the Gulf of Aden is now being considered as a zone of extreme danger and as such an insurance risk premium is being applied. Crew now receive a wage supplementation whilst travelling through the region ${ }^{8}$. Time charter rates per day are a measure of capital, crew, maintenance costs etc of operating the ship. As voyage length varies so too will the number of days to complete a round voyage. This variable will be taken up later and is not included at this stage in (4). Thus

$$
\Delta C_{V}=\left(F_{C}-F_{S}\right)-\left(S C_{R}+I+W_{S}\right)
$$

where

$$
\begin{aligned}
\Delta C_{V} & =\text { incremental cost per round voyage } \\
F_{C} & =\text { Fuel costs via Cape of Good Hope } \\
F_{S} & =\text { Fuel costs via Suez } \\
S C_{R} & =\text { Suez Canal transit rates, north and southbound } \\
I & =\text { Insurance risk premium for Suez north and southbound } \\
W_{S} & =\text { Wage supplementation for Suez north and southbound }
\end{aligned}
$$

Two vessel types were chosen for the analysis, a tanker and a large container ship. For the purposes of the comparative study a VLCC with similar size, engine power and speed as the

\footnotetext{
${ }^{8}$ Peter Bond GM of Cyprus based Interoient Line Services reports that the company pays its crews double for every day spent in the Gulf of Aden. They are also considering hiring licensed security guards, costing $\$ 60,000$ per trip to protect the crew (Miller 2008).
} 
Sirius Star was chosen as this size of vessel has already been targeted by pirates. A 10,020 TEU container ship was chosen as decisions have already been made by the major container operators to divert their larger container vessels around the Cape, avoiding the Suez Canal. Table 2 lists ship characteristics of both vessels used in the analysis.

Table 2 Ship characteristics

\begin{tabular}{|l|l|l||}
\hline & VLCC & Container Vessel \\
\hline \hline Tonnage & $162,252 \mathrm{GT}$ & 147,716 tons displacement \\
\hline \hline DWT/TEUs & $318,000 \mathrm{DWT}$ & 10,040 \\
\hline \hline NRT & 111,896 tons & 54,951 tons \\
\hline \hline Length & $332 \mathrm{~m}$ & $349 \mathrm{~m}$ \\
\hline Breadth & $58 \mathrm{~m}$ & $45.66 \mathrm{~m}$ \\
\hline Draft & $22 \mathrm{~m}$ & $27.3 \mathrm{~m}$ \\
\hline \hline Main Engines & Man $6 \mathrm{~S} 90 \mathrm{M}-\mathrm{C}$ & Man $12 \mathrm{~K} 98 \mathrm{ME}$ \\
\hline \hline Power output & $29,340 \mathrm{~kW}$ & $68,640 \mathrm{kw}$ \\
\hline \hline Service Speed & $16.2 \mathrm{knots}$ & $25.8 \mathrm{knots}$ \\
\hline
\end{tabular}

Source: Lloyds Register of Shipping.

To avoid being confounded by extraneous variables, voyages were assumed between port pairs with no other port calls. The tanker port pairs are the oil port of Mena al Ahmedi in Kuwait and Rotterdam in Europe and for the container ship, the trade route Singapore to Rotterdam, The comparative distance, sea time per round trip for the route by Suez and via the Cape of Good Hope are presented in Table 3 for the VLCC and for the 10,040 TEU container ship in Table 4 The sea time for a single leg was calculated for each route using the manufacturer's stated service speed. To calculate the round voyage time, port and transit times for the Suez Canal were added. Four decimal places are used throughout the analysis until the final calculations of the cost of piracy to minimise rounding errors. To allow for loading, discharging, tide and other factors two days at each end of the route were assumed. Two days were allowed for transit of the Canal. 
Table $3 \quad$ VLCC round voyage

\begin{tabular}{|l|r|r|}
\hline Mena al Ahmedi to Rotterdam & Via Suez & Via Cape \\
\hline \hline Distance in NM & 6,577 & 11,369 \\
\hline \hline Round Voyage in days & 39.8248 & 62.4826 \\
\hline
\end{tabular}

Source: Reeds Marine Distance Tables

Table 4 Container ship round voyage

\begin{tabular}{|l|r|r|}
\hline Singapore to Rotterdam & Via Suez & Via Cape \\
\hline \hline Distance in NM & 8,308 & 11,850 \\
\hline \hline Round Voyage in days & 32.8346 & 42.2752 \\
\hline
\end{tabular}

Source: Reeds Marine Distance Tables

To determine the fuel cost per annum we need to return to (3). $F$, fuel cost for the voyage, is a function of the length of a sea-time round voyage in days, the specific fuel consumption in tonnes per day and the price of bunkers. The power of the engine and the consumption in grams per kilowatt for the manufacturer's stated service speed of the vessel are used to determine the fuel consumption in tonnes per day. This value was calculated for both vessels and is the second item in Tables 5 and 6. Fuel consumption for the VLCC is 117.5847 tons per day and 280.0512 tons per day for the container vessel. The use of ancillary engines and fuel consumption while in port do not form part of the analysis as these costs would be constant across routes. If $T$, the time period, is a year then the number of voyages completed in the year equals the length of each round voyage including sea-time, port and canal transit times, in the case of the Suez route, divided into 365 days. Bunker cost was based on 380cst marine fuel oil @ \$260/t. The specific fuel consumption of each vessel in tonnes was calculated on a hourly then daily basis and was found to $117.5947 \mathrm{t} / \mathrm{day}$ for the VLCC and $280.0512 \mathrm{t} /$ day for the container ship ${ }^{9}$. The fuel consumption per round voyage was based on the sea-time length of each round voyage. These values were used to find the total fuel cost per annum for both the tanker and container vessel on Suez and Cape routes, the last item in Tables, 5 and 6.

\footnotetext{
${ }^{9}$ For more detail on fuel consumption calculations see (H.B.Bendall 1979).
} 
Table 5 VLCC sea-time fuel costs pa.

\begin{tabular}{|l|r|r|}
\hline Mena al Ahmedi to Rotterdam & Via Suez & Via Cape \\
\hline \hline Sea-time per round voyage & 33.8248 & 58.4826 \\
\hline \hline Fuel Consumption $\mathbf{~ / d ~}$ & 117.5947 & 117.5947 \\
\hline \hline Fuel Consumption t / $\mathbf{~ v ~}$ & $3,774.6684$ & $6,526.3482$ \\
\hline \hline No of round voyages pa & 9.1651 & 5.8416 \\
\hline \hline Fuel Oil* Cost \$s per year & $\$ 9,478,367.47$ & $\$ 10,445,267.92$ \\
\hline
\end{tabular}

Source*: \$260/t (Clarkson 2009).

Table 6 Container ship sea-time fuel costs pa.

\begin{tabular}{|l|r|r|}
\hline Singapore to Rotterdam & Via Suez & Via Cape \\
\hline $\begin{array}{l}\text { Sea-time days per round } \\
\text { voyage }\end{array}$ & 26.8346 & 38.2752 \\
\hline \hline Fuel Consumption t/d & 280.0512 & 280.0512 \\
\hline \hline Fuel Consumption t / r v & $7,515.0619$ & $10,719.0157$ \\
\hline No of round voyages pa & 11.1163 & 8.6339 \\
\hline \hline Fuel Oil* Cost \$s per year & $21,720,317.48$ & $24,062196.51$ \\
\hline
\end{tabular}

Source*: \$260/t (Clarkson 2009).

\subsection{Opportunity Cost of Diversion for a Constant Freight Task}

As the voyage around the Cape adds considerably to the length of the voyage, fewer voyages have been shown to be completed in a given time period, $T$, one year. Ships on this route have lower productivity as they carry less cargo volumes each year. Thus there is an opportunity cost of diversion, $C_{O C}$, which is a function of the number of lost voyages per period when the Cape route is taken. For a comparative route costing analysis, the freight task, ie the amount of cargo carried by the ship on each route, should be constant to ensure that the revenue function, $R$, described in (2) remains a constant ${ }^{10}$. To isolate the additional

\footnotetext{
${ }^{10}$ An assumption is made that customers will not demand a lower freight rate for slower delivery of goods.
} 
costs of the fall in productivity of the vessel as a result of the "lost" voyages per period and still hold the revenue function constant, two approaches can be taken. In the first approach the shipowner would need to charter-in an extra vessel to carry the shortfall in the freight task. The charter cost of the vessel would need to be included. In the second approach the shipowner would need to extend the number of voyages of the same vessel and the cost of these voyages would also need to be factored in. Ceteris paribus, both approaches are a measure of the opportunity cost of diversion, however in the first, $T$ remains a constant but in the second $T$, becomes a variable. It is the second approach that will be undertaken in this analysis. If $H$ is the constant freight task ie the cargo commitment to clients, is taken to be the volume of cargo carried by the vessel using the shorter Suez route over a year, the diversion cost of carrying $H$, including opportunity cost, equals the cost of piracy, $C_{P}$. In (4) the incremental costs of diversion were identified as the differential in fuel costs between the two routes, offset by the costs of canal transit. The cost of piracy will include these factors but as well, an opportunity cost, $C_{O C}$.

\subsubsection{The Elements of the Opportunity Cost}

Ships are expensive assets. A charge or opportunity cost should be included to reflect the additional time/capital costs necessary to complete $H$. Time charter rates per day will be used for this purpose and are denoted as $\Delta C_{C H}$. Time charters also cover crew costs over the period $^{11}$. The additional voyages around the Cape will incur fuel costs, $\Delta C_{F H}$, additional Protection and Indemnity, $\mathrm{P} \& \mathrm{I}$, insurance cover $\Delta C_{I H}$ and additional port visit costs, $\Delta C_{P H}$. If $\mathrm{H}$ is the constant freight task then the opportunity cost, $\mathrm{C}_{\mathrm{OC}}$, equals

$$
\text { where } \quad \begin{aligned}
C_{O C} & =\Delta\left(C_{C H} C_{F H}+C_{I H+} C_{P H}\right) \\
\Delta C_{C H} & =\text { incremental charter cost to fulfil } H \\
\Delta C_{F H} & =\text { incremental fuel cost to fulfil } H \\
\Delta C_{I H} & =\text { incremental insurance cost to fulfil } H \\
\Delta C_{P H} & =\text { incremental port costs to fulfil } H
\end{aligned}
$$

The opportunity cost, $C_{O C}$ is now incorporated into the model to form (6)

$$
C_{P}=\left(F_{C}-F_{S}\right)+\left(S C_{R}+I+W_{S}\right)+C_{O C}
$$

The cost of piracy, $C_{P}$. equals the differential in voyage fuel costs over the given time $T$, the first term on the right hand side, minus the savings in costs associated with using the Suez route to carry $H$ ie Suez rates, insurance risk premium and wage supplements for "war zone" transit, the second item on the right hand side, plus the costs associated with the extra voyages to ensure a constant freight task $H$.

\footnotetext{
${ }^{11}$ If a shipowner chooses not to extend the number of voyages but completes the freight task in time $T$, an extra vessel could be chartered in, incurring a similar cost.
} 


\section{RESULTS}

It is assumed that the tanker will carry its full deadweight load of 318,000 tons per voyage. A payload of 0.8 however is assumed for the container vessel as actual container carrying capacity is usually lower that the stated number of TEUs provided by the builder and equals 8,032 TEUs per single voyage. Via Suez, the VLCC will complete 9.1651 round voyages and thus over the period of a year will carry 2,914,501 tons. The container vessel over the same period will complete 11.1163 round voyages and carry 178,572.2432 TEUs. Again four decimals places are preserved to avoid rounding inconsistencies until the final analysis. The cargo carrying capacity of both vessels over the year via Suez sets the base for the given freight task, $H$. If the VLCC has been routed via the Cape to avoid the pirates in the Gulf then 3.3235 additional voyages must be made to complete H. Similarly the large container vessel will have to complete an additional 2.4824 voyages. $\left(C_{O C}\right)$, the opportunity cost of this additional freight task, can now be estimated and used in (6). Fuel costs for round voyage only relate to sea-time for both the first item on the right hand side of equation (6) and for the opportunity cost of fuel to complete the additional voyages. Charter costs were supplied by a shipbroker as of the 23 February 2009. Insurance costs for ships of similar size were obtained from industry sources for vessels using the Suez and those avoiding the Gulf of Aden. The opportunity cost components relating to fuel and charter costs were calculated and the results presented in Tables 7 and 8. Other opportunity cost factors such as harbour and light dues for additional port visits, although identified to complete the diversion cost model, are minor and are not included in the analysis. Terminal fees for loading and discharging relate to cargo volumes. As the freight task is constant then the route is immaterial to the cargo volumes carried. As cargo is constant, terminal costs do not form part of the opportunity costs of diversion.

Table 7 Opportunity cost (fuel) to complete freight task.

\begin{tabular}{|l|r|r|}
\hline & VLCC & Container Ship \\
\hline \hline Additional voyages to complete $\mathbf{H}$ & 3.3235 & 2.4824 \\
\hline \hline Round sea voyage days- via Cape & 58.4826 & 38.2752 \\
\hline \hline Fuel consumption t/day & 117.5947 & 280.0512 \\
\hline \hline Bunker cost 380cst* & $\$ 260$ & $\$ 260$ \\
\hline Additional fuel cost to complete $\mathbf{H}$ & $\$ 5,942,695.14$ & $\$ 6,918,309.98$ \\
\hline
\end{tabular}

Source*: Clarkson 2009 
Table 8 Opportunity cost (charter) to complete freight task.

\begin{tabular}{|l|r|r|}
\hline & VLCC & Container Ship \\
\hline \hline Additional voyages to complete $\mathbf{H}$ & 3.3235 & 2.4824 \\
\hline \hline Voyage sea-days around Cape & 62.4826 & 42.2752 \\
\hline Charter Cost / day & $\$ 40,000$ & $\$ 17,500$ \\
\hline \hline Additional charter cost to complete $\mathbf{H}$ & $\$ 8,306,436,84$ & $\$ 1,836,519.24$ \\
\hline
\end{tabular}

The Suez Canal Authority Rates were obtained for northbound and sound bound transits for both the 318,000 dwt VLCC and 10,040 TEU container vessel. The VLCC southbound voyage would be in ballast so canal transit rates are lower for this leg. There is only a slight difference between north and southbound rates for the container vessel. Suez rates are $\$ 624,304.66$ /round voyage for the VLCC and $\$ 547,885.31$ for the container vessel. These rates were applied to each round voyage to complete the freight task $\mathrm{H}$ in one year time period and are $\$ 5,721,814.33$ for the VLCC and $\$ 6,090,457.51$ for the containership. The results are presented in Table 9.

Table 9 Suez Canal transit costs.

\begin{tabular}{|l|r|r|}
\hline & VLCC & Container Ship \\
\hline \hline North bound & $345,464.786$ & $274,189.6565$ \\
\hline \hline South bound & $278,839.874$ & $273,695.6565$ \\
\hline \hline Total in USD & $624,304.626$ & $547,885.3130$ \\
\hline \hline No of voyages/year & 9.1651 & 11.1163 \\
\hline \hline Cost to complete cargo task & $\$ 5,721,814,32$ & $\$ 6,090,375.26$ \\
\hline
\end{tabular}

There is currently a wage supplement paid to crew while transiting the region. As this crew payment is only for approximately a week per voyage and varies with crew nationality, the bonus is relatively minor in perspective to other Suez costs and is not included in the costing.

The Suez insurance risk premium for P\&I cover was based on the number of transits of the Suez Canal necessary to complete $H$. The risk premium rate for the Suez route is quite substantial due to the spate of pirate attacks on larger and larger vessels in recent times and 
has certainly been a major factor along with hefty Suez Canal rates in the decision by shipping lines to divert to the Cape route. Although insurance rates will vary with the size and composition of the shipowner's fleet, estimates obtained for P\&I insurance of vessels of similar size to those in the study indicate that the risk premium per transit of Suez is extremely high. For example a rate of $0.1 \%$ of the ship value was applied to each Suez transit in addition to an annual rate of $0.15 \%{ }^{12}$. The insurance risk premium for each transit of the Suez was $\$ 130,000$ for the VLCC and $\$ 100,000$ for the container ship, based on ship values supplied by Clarkson (2009). These transit insurance costs were applied to the number of voyages per year via Suez for each vessel. The insurance opportunity cost component was found by apportioning the number of extra days necessary to complete $H$ as a percentage of the annual insurance P\&I rate. Using the model outlined in (6) the cost of piracy for the VLCC is $\$ 7,222,234.24$ per annum and $\$ 2,842,735,82$ a year for the container vessel, shown in Tables 10 and 11. The diversion cost is significant for both vessel.

Table 10 Cost of piracy - VLCC

\begin{tabular}{||l|l|r|}
\hline VLCC & & USD \\
\hline \hline Additional Fuel Costs Cape & & $966,900.45$ \\
\hline \hline Opportunity Cost of $\mathbf{H}$ & Fuel & $5,942,695.14$ \\
\hline \hline & Charter & $\mathbf{8 , 3 0 6 , 4 3 6 . 8 4}$ \\
\hline \hline Savings via Suez Canal & Insurance & $110,942.14$ \\
\hline \hline & Suez Canal dues & $5,721,814.33$ \\
\hline \hline Cost of Piracy & Insurance risk premium & $\mathbf{2 , 3 8 2 , 9 2 6 . 0 0}$ \\
\hline
\end{tabular}

12 Marcus John, CEO Thomas Miller, Australia 26 February 2009.. 
Table 11 Cost of piracy - Container ship

\begin{tabular}{|l|l|r|}
\hline \multicolumn{1}{|l|}{ Container Ship } & \multicolumn{2}{|c|}{ USD } \\
\hline \hline Additional Fuel Costs Cape & & $2,358,600.70$ \\
\hline \hline Opportunity Cost of $\mathbf{H}$ & Fuel & $6,918.309 .98$ \\
\hline \hline & Charter & $1,836,519.24$ \\
\hline \hline & Insurance & $43,023.41$ \\
\hline \hline Savings via Suez Canal & Suez Canal dues & $6,090,457.51$ \\
\hline \hline & Insurance risk premium & $2,223,260.00$ \\
\hline \hline Cost of Piracy & & $\$ 2,842,735.82$ \\
\hline
\end{tabular}

If piracy remains unabated in the region and ships are forced to re-route on a more permanent basis then the comparative voyage costing approach could be expanded to include a discounted cash flow analysis, DCF, in order to measure the impact of diversion over time on the value of the shipping company. This is an area for future research.

On a purely cost basis, why then are shipping companies choosing to re-route via the Cape?

It has been demonstrated there are significant savings from avoiding Suez Canal transit fees and the hefty risk premium insurance for ships travelling through the Gulf of Aden but the additional fuel costs of the longer voyage are not the only consideration. The savings generated have been shown to be insufficient to offset the considerable opportunity cost of the longer voyage. However, in today's economic climate the shipping industry is experiencing a downturn with economic activity depressed worldwide. It is reported that over 453 container ships, $10.7 \%$ of world fleet (Lloyds List 2009c) have been laid up, including new builds which are yet to see service. The depressed demand is reflected in the lower charter rate of $\$ 17,500$ / day for a new 10,040 TEU vessel used in the analysis to determine the opportunity costs of the additional voyages. Had the current market for box ships been more buoyant, the time charter rate would be more reflective of the capital cost of the new vessel. In this was the case, the cost of piracy for the container ship operator would have been more marked. Shipping lines with advertised port service commitments are using the opportunity to employ vessels which may otherwise be laid up to maintain their scheduled port visits. By doing so, shipping companies do not have to cut the service to their customers, nor have to charter-in additional tonnage to compensate for slower steaming times on the longer route. The opportunity cost component is thus reduced but this savings in charter costs would need to be adjusted further to take into account lay-up costs. This is an area for future research. 


\section{CONCLUSION.}

Maritime piracy has been on the rise for a number of years. Pirates have become more sophisticated and are targeting larger and larger vessels. Recently the spate of pirate attacks in the Gulf of Aden near Somalia and the southern entrance to the Red Sea, including the ransom of largest ship ever, the VLCC Sirius Star in November 2008 has focused world attention on the issue. Insurance premiums for transit of the region have soared to a point where annual P\&I insurance rates are similar to the risk premium applied to a single voyage. Ships can avoid the region by re-routing via the Cape of Good Hope. However this diversion may add considerable distance to any trade route. For the ships and trade analysed, diversion added $74 \%$ to length of the voyage from Kuwait to Rotterdam in the case of the tanker and $44 \%$ for the container vessel in the Singapore to Rotterdam route. The cost of diversion is the cost of piracy from the shipowner's point of view. A comparative voyage costing approach was undertaken. By analysing a constant freight task, defined as the amount of cargo carried in a year via Suez, the study found that re-routing added a considerable cost penalty. Millions of dollars were added to fuel bills and the longer route incurred an opportunity cost of less voyages in a given time period to carry the same amount of cargo as through the Suez. However the cost of diversion, and thus the cost of piracy, would be greater if there were no substantial incentives to avoid the area. Insurance risk premiums and canal transit fees offset to a great extent the additional fuel and opportunity costs, reducing the cost of piracy to the shipowner. Nevertheless, there is a net cost. Piracy is adding millions of dollars per year to shipwowners' costs each year when opportunity costs are factored in. If piracy is not combated and continues to grow, it will have serious consequences for international transport and trade, affecting both developed and developing economies. 


\section{REFERENCES.}

Abdul Bashi, Ashaba, K. (2008) Shipping insurance costs may double due to rise in piracy. Zawya Middle East Business Information .viewed 5 February 2009 http://zawya.com/Story.cfm/sidZAWYA20081120042020/Shipping.

Abrams, Joseph (2008) Mysterious cargo aboard Iranian ship raises concern about WMD Concerns. Fox News . 30 Septmeber Viewed 23 February,2009 http://www.foxnews.com/story/0.2933,430681,00.html.

Bendall, H,B, (1979) Coal-fired turbines versus diesel: An Australian context. Maritime Policy and Management. Vol 6. No 3 209-215

Bone, Jeni (2008) Piracy costs industry \$16bn. Sail-World.com. News. 23 August.

Clarkson (2009) Clarkson Shipping Intelligence Weekly No 85416 January. ISSN 1358-8028

Cordingly, David (Ed) (2006) Pirates. Terror on the High Seas - From the Caribbean to the South China Sea. North Dighton, M.A: World Publications.

Collyer, Sam (2009) Piracy attacks down but new wave expected Lloyds List DCN 23 February, Viewed 23 February 2009. http://lloydslistden.com.au/informaoz/LLDCN/Components/News/Print_version.

Costello, Miles. (2008) Shipping insurance cost soars with piracy surge off Somalia. Times On Line. 11 September. Viewed 3 February,2009. http://www.timesonline.co.uk/tol/business/industry_sectors/banking_and_finance/arti cle4727372.ece

Dillon, Dana Robert (2000) Piracy in Asia: A Growing Barrier to Maritime Trade. The Heritage Foundation. 22 June. Viewed 23 January 2009.. http://www.heritage.org/research/asiaandthepacific/bg1379.cfm

Fetouh, Sayed.A (2008) Suez Canal and its role in Global Trade. Proceedings $33^{\text {rd }}$ Transportation Research Board, TRB Summer Conference. Baltimore, Maryland. June

Gettleman, Jeffrey (2009) Holding the world to ransom. The Sun Herald. 25 January

Hanson, Stephanie (2009) Combating Maritime Piracy Council on Foreign Relations. New York: Council on Foreign Relations. January. Viewed 28 January htpp://www.cfr.org/publication/18376/

House of Commons (2006) Select Committee on Transport $8^{\text {th }}$ Report. Viewed 3 March 2009 http://www.publications.parliament.uk/pa/cm200506/cmselect/cmtran/1026/102606.h tm 
IMB (2009)a Live Piracy Map viewed 3 3Marcch Viewed 3 March http://www.iccccs.org/index.php?option=com_fabrik\&view=visualization\&controller =visualization.googlemap\&Itemid=219

IMB (2009)b IMB Reports unprecedented rise in maritime hijackings ICC Commercial Crime Services. Viewed 3 February 2009. http://www.icc-ccs.org

IMO (2000)a Piracy and armed robbery at sea. Focus on the IMO. International Maritime Organization. January Viewed 3 February 2009.. http://www.imo.org

IMO (2008)b. Piracy in waters off the coast of Somalia . International Maritime Organization .Viewed 30 January. http://www.imo.org

IMO (2009) High-level meeting in Dijbouti adopts a Code of Conduct to repress acts of piracy and armed robber against ships. International Maritime Organisation. Viewed 30 January 2009 http:// www.imo.org?newsroom/mainframe.asp?topic_id=1773

ICS (2008)a Shipping world in piracy crisis call to IMO and UN. International Chamber of Shipping 17 September 2008.Viewed 23 January 2009.

http://www.marisec.org/news/index.htm

ICS (2008)b Pirates in Somalia threaten Lives of seafarers and the security of world trade inadequate response by governments is unacceptable. International Chamber of Shipping. 29 September 2008. Viewed 23 January 2009. http://www.marisec.org/news/index.htm

Law Lords (1997) House of Lords - Semco Salvage and Marine PLC v Lancer Navigation..Viewed 3 February 2009 http://www.publications.parliament.uk/pa/ld199697/ldjudgmt/ldjudgmt.htm

Lloyds List (2009)a "Diversion plans could see Nemo service go via the Cape" Lloyds List DCN 28 January 2009

Lloyd List (2009)b MOL joins Suez exodus in Cape diversion plan. Lloyds List DCN. 24 February 2009. Viewed 25 February 2009. http://www.lloydslistden.com.au/informaoz/LLDCN/components/news

Lloyds List (2009)c One in10 container ships now idle. Lloyds List DCN 5 March 2009. Viewed 6 March. http://www.lloydslistdcn.com.au/LLDCN?components/news

Matthews John.(2006) Pirates. Sydney: Harper Collins.

Miller, John, W. (2008) Piracy Spurs Threats to Shipping costs. The Wall Street Journal. 19 November. Viewed 30 January 2009. http://online.wsj.com/article/SB122701864743437147.html

Muncih Re. (2006) Piracy - threat at sea. A risk analysis. Munich Re Knowledge Series. September. Order No 302-05053. 
Murphy Murray N. (2007) Contemporary Piracy and Maritime Terrorism. The International Institute for Strategic Studies. Adephi Papers .AP388. 9 July.

Ostler, David (2009) Suez traffic down 50\%, says agency. Lloyds List DCN 5 February.

Port Strategy (2009) Post Script. Canal Cuts Port Strategy Vol. 1009 Issue 1. January/February.

Porter, Janet (2009) MSC joins Cape move to avoid costly canal route Lloyds List DCN http://www.lloydslistden.com.au

Schiemsky, Bruno (2009) Piracy's rising tide- Somali piracy develops and diversifies. Janes Intelligence Review. 20 January http://www.janes.com/news/security

The Economist (2008)a For those in Peril. The world's insurers are taking a more serious look at robbery on the sea. The Economist. Viewed 6 February 2008. http://www.economist.com/finance/PrinterFriendly.cfm?story_id=6837144.

The Economist (2008)b Peril on the high sea. The Economist. Viewed 3 February 2009. http://www.economist.com/daily/chartgallery/displaystroy.cfm?story_id=11079332

The Economist (2008)c The most dangerous seas in the world. The Economist. 17 July..Viewed 6 February 2009. http://www.economist.com/world/mideast?printerFreiendly.cfm?story_id=117513

The Economist (2008)d . Ahoy there! The pirates of Africa's most failed sate get ever more ambitious and dangerous The Economist, 19 November. Viewed 6 February 2009 http://www.cconomist.com/world/mideast-africa?printerFriendly.cfm?story id 126502.

The Economist (2008)e . Somalia. Ahoy there! The significance of the latest attacks by Somali pirates.The Economist, 20 November. Viewed 6 February 2009 http://www.cconomist.com/world/mideast-africa?printerFriendly.cfm?story id 126273.

Vallar, Cindy (2000) Pirates and Privateers. The History of Maritime Piracy. The cost of Piracy Modern Piracy Part 3. Viewed 20 January 2009. http://www.cindyvallar.com/modern3.html 